\title{
ТРАНСНАЦИОНАЛНА УМРЕЖЕНОСТ ВИСОКОКВАЛИФИКОВАНЕ РАДНЕ СНАГЕ ДИЈАСПОРЕ И РАЗВОЈ СРБИЈЕ
}

Апстракт: Међусобна умреженост појединаца који живе у различитим деловима света изван земље порекла, која подразумева осећај припадности истом народу, као и емотивну, духовну и материјалну повезаност са матицом (која може бити и само замишљена) стоји у суштини појма дијаспоре. Овај појам као и појам транснационализма јесте производ дрштвених феномена у савременом свету и често се међусобно мешају. Стога, треба имати на уму да иако је појам транснационализма настао да означи умрежености миграната истог порекла који живе у различитим земљама, он је шири од појма дијаспоре и обухвата сваку сарадњу која се одвија независно од националних граница држава. С друге стране, појам дијаспоре, премда ужи од појма транснационализма, стоји у нераскидивој вези са њим - да нема умрежености исељеника, не бисмо говорили о дијаспори већ о расејању. Даље, када нема транснационалне умрежености, миграције су чист губитак у сваком смислу за земљу порекла. Повезаност исељеника, спремност на сарадњу и улагање хуманог, социјалног и економског капитала представља значајан ресурс за развој свих друштвених подсистема матице. Циљ овог рада је да на основу резулатата емпиријског исраживања које је НВО „Центар за живот“ реализовала током 2018. године у сарадњи са Кабинетом за демографију и популациону политику и Републичким заводом за статистику, испита у којој мери се српска дијаспора може сматрати важним потенцијалом развоја Србије. С тим у вези, биће приказана образовна и економска структура испитаника, њихова спремност да улажу капитал у земљу порекла, као и препоруке у погледу услова сарадње које су упутили одговорним актерима у земљи.

Кључне речи: транснационализам, дијаспора, мреже, социјални капитал, јавне политике

1 milica.ves@gmail.com 


\section{Увод}

Србија има бројну и професионално разноврсну дијаспору која се налази широм света. Крајем XIX и почетком XX века, становништво са територије данашње Србије и држава где су Срби аутохтоно становништво, махом је одлазило у правцу прекоокеанских држава, првенствено САД и земље Јужне Америке (Filipović, 2012). Неки од њих, попут Михаила Пупина, су се, макар привремено враћали у ратном периоду када су осетили да су матици најпотребнији. Одлазак наших људи, међу којима је значајан број образованих и врло стручних, па и широко познатих појединаца се наставља, а још интензивнији постаје након кључних догађаја, који често подразумевају извесне друштвено-економске кризе српског друштва. Велики број претежно младог становништва напустио је Србију током распада социјалистичке заједнице који је био праћен ратним разарањима (Гречић, 2010; Filipović, 2012). Тих година живот у земљи је био додатно отежан економском кризом коју је, поред уведених међународних санкција, изазвала и трансформација социјалистичког у капиталистички систем, која још увек није до краја окончана (Лазић и др, 2014). Смиривање сукоба, а нарочито промена власти на почетку новог миленијума давала је наду за опоравак свих друштвених подсистема, а тиме и наду у повратак младих талентованих људи из иностранства, као и наду у мањи удео потенцијалних миграната међу становништвом. Премда су се људи на почетку враћали у земљу са вером у напредак, недовршена транзиција која се показивала у очувању негативних обележја старог система и политичка нестабилност, уз личне разлоге појединаца, учинили су да се одлазак из Србије настави.

Чињеница која одвраћа од апсолутног песимизма због емиграције младог, радно способног становништва који поред хуманог потенцијала, услед својих година које су оптималне за рађање, представљају и демографски потенцијал, лежи у пракси других, углавном западних развијених земаља које у дијаспори виде равноправног партнера за развој друштва (Гречић, 2010). Наиме, анализе привреда развијених држава указују на предности давања приоритета креирању, ускладиштењу, коришћењу и трансферу знања, као неопходних услова развоја. Свесне да знање расте једино ако се примењује у новим условима и размењује са другим достигнућима, ове државе подстичу своје образоване младе људе да 
одлазе у друге земље и раде на богаћењу људског капитала². Успех у подстицају на мобилност огледа се и у чињеници да се оне издвајају по уделу високообразованих становника у целокупном броју светске миграционе популације (Мороквашић, 2011: 16). Међутим, оно што је у томе било пресудно јесте креирање, примена и очување таквих јавних политика које негују везе са својим грађанима који живе ван матичне државе чиме они не постају отуђени, већ остају емоционално и на друге начине везани за своју земљу порекла. Тако они не постају губитак за земљу порекла, они нису просто расејање 3 , већ их та веза чини дијаспором која има веома широк развојни потенцијал.

Укључивање дијаспоре у развојне пројекте у земљи порекла у многоме је поједностављено и развојем модерне технологије која олакшава комуникацију међу појединцима и групама. Захваљујући интернету и модерној телефонији размена информација је тренутна и за обављање многих делатности више и није неопходна физичка присутност свих учесника већ се размена идеја и резултата одвија преко програма специјално креираних у те сврхе. Применљивост модерних технологија као и њена ефикасност дошла је до изражаја нарочито током пандемије вируса COVID-19, када се комуникација усмерена на реализацију пословних планова и задатака, где год је то било могуће, одвијала на овај начин. Независно, међутим, од новонастале ситуације, па и деценијама пре актуелне здравствене кризе, уочено је да се пословна и свака друга сарадња

2 Поред тога што подстичу своју образовану елиту да „скупља“ знање преко граница, свесне значаја научног и технолошког напредовања, западне земље креирају такве имиграционе политике које се у исто време са пооштреним режимима за азиланте и необразовано становништво крећу у смеру привлачења високообразованих и стручних миграната, највише из неразвијених и земаља у развоју, што постаје њихова водећа стратегија. Неки аутори (Chua, A, 2007; Florida, 2003, наведено према Гречић: 2010) сматрају да доминација ових држава своје корене и има у доброј тактици привлачења талената и предузимљивих странаца.

3 За постојање дијаспоре важно да становништво које живи ван земље порекла препознаје матицу као центар и основ заједничког идентитета, да постоји међусобна повезаност појединаца истог порекла као и „одржавање чврстих менталних и материјалних веза са њиховом земљом порекла - њиховом домовином“ (Sheffer, 1986: 3). У случају да не постоји однос међу појединцима који не живе у земљи порекла и да се не препознаје усмеравање њихових ресурса у добробит друштва матичне државе, тада не говоримо о дијаспори, већ о расејању (Ma Mung, 2004: 211). У том случају свака расправа о њиховом укључивању у потенцијални развој земље, постаје бесмислена. 
која превазилази границе националне државе интензивирала, па су научници разних области (углавном социолози, економисти и политиколози) сковали и нови термин да означе овај феномен модерног доба - транснационализам. Првобитно, он се односио само на сарадњу међу мигрантима истог порекла4, међутим, касније овај појам се проширује на сваку сарадњу међу појединцима у различитим деловима света која се одвија независно од било које државе (што овај појам и одваја од појма глобализације), па укључује и терористичке организације, разна удружења грађана, предузетништво и политичка деловања. Ипак, транснационализам се и даље најчешће везује за дијаспору, па и више од тога: да нема умрежености појединаца које спаја заједнички идентитет не би било ни дијаспоре (Pries, 2005). При томе ипак треба имати на уму да се дијаспора разликује од транснационализма јасним издвајањем матице, која поред тога што представља корен заједничког идентитета као центра уједно јесте и центар на који је усмерен интерес размене добара појединаца.

Имајући у виду политике развијених земаља са видљивим резултатима интензивне сарадње са дијаспором, на првом месту висококвалификованом, НВО „Центар за живот“ у сарадњи са некадашњим Кабинетом за демографију и популациону политику и Републичким заводом за статистику спровео је истраживање на тему карактеристика и ставова висококвалификоване дијаспоре и повратника са циљем мапирања српске научне дијаспоре, њихових ресурса, као и мотива за улагање у овдашњи развој, што би требало да представља основу за креирање будућих ефективних јавних политика са овим циљем (Ђукић Дејановић, 2018). Наиме, идеја је да се прикупе подаци који би се могли користити у креирању јавних политика са циљем стварања повољне климе која би олакшала, а и подстакла сарадњу наше дијаспоре широм света. Сврха таквих политика државе би поред уважавања богаћења личних ресурса појединаца чланова дијаспоре и њиховог задовољства боравком, за циљ имала и осмишљавање и реализацију развојних пројеката у Србији. Поред тога, издвајају се и посебни циљеви пројекта:

\footnotetext{
4 Рандолф Бурн (Randolph Bourne) га је још 1916. употребио да би описао прекограничне односе имиграната у Сједињеним Америчким Државама (Vertovec, 2001, 2002; Faist, 2000; Glick Schiller, 2003: 100; Portes, 2007: 251; Bradatan et al. 2010)
} 
1) да се стекне оквирна слика о социо-демографском профилу наше високообразоване дијаспоре,

2) да се мапирају расположиви ресурси које су стекли, а које би, ако се стекну неопходни услови, могли да усмере у развој Србије,

3) да се процени степен њихове емотивне везаности за Србију која укључује и тест лојалности,

4) да се прикупе конкретни предлози за измену и/или креирање нових државних политика како би се створила подстицајна клима за њихово учешће у развоју Србије.

У овом раду биће приказан један сегмент истраживања који се односи на степен умрежености дијаспоре и потенцијале развоја у смислу спремности испитаника да усмере свој капитал у развој Србије.

\section{Методологија истраживања и опис узорка}

Истраживање карактеристика и ставова висококвалификоване дијаспоре и повратника спроведено је у периоду од 16. октобра до 21. новембра 2018. године. За потребе истраживања развијена је посебна .NET апликација. Реч је о квантитативном истраживању које је било усмерено на грађане који Србију препознају као матичну земљу независно од тога којој генерацији исељеника припадају. Међутим, важно је било да је период који проводе ван Србије дужи од годину дана и да су према степену образовања стекли најмање диплому основних студија. Упитник је дистрибуиран преко друштвених мрежа и интернет портала постављањем линка, затим преко дијаспорских организација у земљи и иностранству. Пратећи линк који су добили испитаници су самостално одговарали на питања. То даље имплицира да карактеристике самог узорка нису раније биле одређене, већ је попуњавање текло слободно и без критеријума. Стога, можемо рећи да није реч о репрезентативном узорку и да анализе и закључци који буду у раду изнесени не могу бити генерализовани на читаву висококвалификовану дијаспору Србије. Пре бисмо могли да претендујемо на дескриптивну анализу ставова и доживљаја само оних испитаника који су попунили упитник. 
У истраживању су учествовала 353 високообразована лица. Број мушкараца и жена је скоро изједначен, 177 мушкараца и 176 жена. Посматрано по петогодишњим старосним групама, најзаступљенија су лица старости 30-34 године (укупно 65 лица, односно 18,4\% анкетираних). Као што можемо видети на табели 1. жене су нешто бројније од мушкараца у млађим старосним групама (20-24, 25-29 и 30-34 године), док су мушкарци бројнији у свим осталим старосним групама, осим у групи 40-44 године у којој је број мушкараца и жена изједначен.

Табела 1. Анкетирана лица према полу и старости (у \%)

\begin{tabular}{l|c|c|c|c|c|c|c|c|c|c|c}
\hline Свега & 100 & 7.1 & 12.7 & 18.4 & 16.4 & 11.9 & 9.6 & 7.1 & 7.9 & 5.1 & 3.7 \\
Мушкарци & 100 & 5.6 & 6.2 & 16.4 & 18.1 & 11.9 & 10.7 & 8.5 & 11.9 & 5.6 & 5.1 \\
Жене & 100 & 8.5 & 19.3 & 20.5 & 14.8 & 11.9 & 8.5 & 5.7 & 4.0 & 4.5 & 2.3
\end{tabular}

Извор: истраживање „Карактеристике и ставови висококвалификоване дијаспоре и повратника“

Просечна старост учесника анкете износи 40,8 година, при чему су мушкарци за око пет година старији од жена (просечна старост: мушкарци 43,5 година, жене 38,2 године). Већина учесника анкете рођена је у Републици Србији (83\% је рођено у Србији, $17 \%$ је рођено у иностранству). Међу анкетираним лицима која су рођена ван Републике Србије, највећи број лица рођен је у некој од бивших република СФРЈ, односно државама где су Срби аутохтоно становништво - укупно 51 лице, односно 85\% од укупног броја рођених у иностранству.

Посматрано према економској активности, већина анкетираних је запослена (80\%), следе студенти (15,6\%), док је знатно нижи удео незапослених лица $(1,7 \%)$ и пензионера (2\%). Структура према економској активности значајно се разликује у зависности од пола испитаника. Наиме, међу анкетираним мушкарцима 86,4\% чине запослена лица, око 10\% студенти и нема незапослених испитаника. С друге стране, међу женама је нешто мање запослених (73,3\%), удео студенткиња (од 21\%) је два пута већи од удела студената међу мушкарцима који су учествовали у анкети, док удео незапослених међу анкетираним женама износи 3,4\%.

Већина анкетираних лица живи у Сједињеним Америчким Државама $(25,2 \%)$ и Немачкој $(22,4 \%)$. На трећем месту према броју анкетираних је 
Канада (7,6\%), следе Аустрија и Аустралија (по 6,5\%), Велика Британија (5,7\%), док је удео учесника анкете из других држава мањи од 5\%. Просечна дужина боравка у иностранству је 11,6 година. При томе, мушкарци у просеку живе 13,5 година у иностранству, док је просечан боравак жена у иностранству краћи за око четири године, тј. 9,7 година.

За већину учесника анкете основни разлог за одлазак из Републике Србије био је "школовање/ усавршавање у иностранству" или "посао". За један од ова два понуђена модалитета изјаснило се преко 72\% анкетираних (школовање/усавршавање - 39\%, посао - 33\%). Око 12\% испитаника отишло је у иностранство из породичних разлога (спајање породице, брак), док је 16\% испитаника навело неки други разлог. Као неки други разлог одласка из Републике Србије испитаници су наводили, пре свега економске разлоге (23,5\%), ратна дешавања на просторима бивше СФРЈ $(19,8 \%)$, друштвено-политичку ситуацију у земљи $(13,6 \%)$, личне разлоге $(11,1 \%)$ и корупцију (8,6\%), док 23,5\% испитаника није навело конкретан разлог због којег су отишли у иностранство.

\section{Анализа резултата и дискусија}

\section{Капитал дијаспоре}

Према подацима Светске банке, укупан прилив дознака из иностранства у Србију је 2020. године износио 3.869 милиона долара, што је био удео од 7,3\%5 у укупном домаћем производу (The World Bank, 2021). C обзиром на то, као и на чињеницу да, судећи према подацима прикупљеним на последњем Попису становништва 2011., око 800.000 људи у Србији живи од прилива новца од наших грађана у иностранству (Станковић, 2014), не чуди да се најчешће мисли на финансијски капитал када се говори о улагању дијспоре у матицу. Међутим, везано за високообразовану дијаспору, још и важнији од тога јесте хумани и социјални капитал који, ако се правилно

\footnotetext{
${ }^{5} \mathrm{C}$ обзиром да је та година обележена кризом изазваном корона вирусом, која није била само здравствена, већ у великој мери и економска пошто су многе делатности обуставиле рад услед здравствених препорука, а многи су отишли на принудне одморе, нарочито странци, прилив средстава је умањен за скоро пола милијарде долара у односу на претходну годину.
} 
усмере и подрже одговарајућим јавним политикама, могу бити конвертовани у финансијски капитал.

Анализирајући хумани капитал дијаспоре, схваћен као знање и способности појединца (Coleman, 1988), држали смо се искључиво формалних индикатора који су операционализовани преко питања о стеченом степену образовања и пољу студирања. Највећи број учесника анкете је стекло титулу доктора наука $40,2 \%$, титулу магистра је стекло њих $8,5 \%$, док је удео лица са завршеним интегрисаним студијама, мастер или специјалистичким студијама и удео лица са дипломом факултета/ академије (по старом програму) изједначен (18,4\%). Укупно 7,1\% анкетираних има диплому основних или струковних студија (по новом програму), а свега 5,9\% је оних који су завршили вишу школу или имају први степен факултета (по старом програму). Посматрано према пољу образовања, највећи број учесника анкете стекао је диплому из области техничко-технолошких наука $(36,8 \%)$, од тога из области информационокомуникационих технологија 14,4\% и осталих техничко-технолошких наука $22,4 \%$. Следе стручњаци из области друштвено-хуманистичких наука, са уделом од 30,6\%, природно-математичких наука (19\%), и медицинских наука $(8,5 \%)$. Удео лица са дипломом из области интердисциплинарних, мултидисциплинарних и трансдисциплинарних студија износи 2,8\%, док је најмањи удео лица са завршеним уметничким факултетима и академијама 1,4\%. Судећи, дакле, према овим подацима, наша високообразована дијаспора је сачињена највише од доктора наука и то највише из области технике и технологије који су у савременом свету и најтраженији за конкурентност на тржишту.

Приликом анализе социјалног капитала српске вискообразоване дијаспоре, држали смо се Патнамовог схватања овог концепта, по којем он „упућује на везе између појединаца - друштвене мреже и норме узајамности и поверења које произилазе из њих“ (Патнам, 2008:20). Поседовање овог ресурса, чији се значај све више увиђа на свим нивоима друштвене стварности, водећи се Патнамовим схватањем овог појма, испитивали смо најпре преко чланства испитаника у професионалним организацијама. Резултати су приказани на графикону . 
Графикон 1. Чланство испитаника у професионалним организацијама

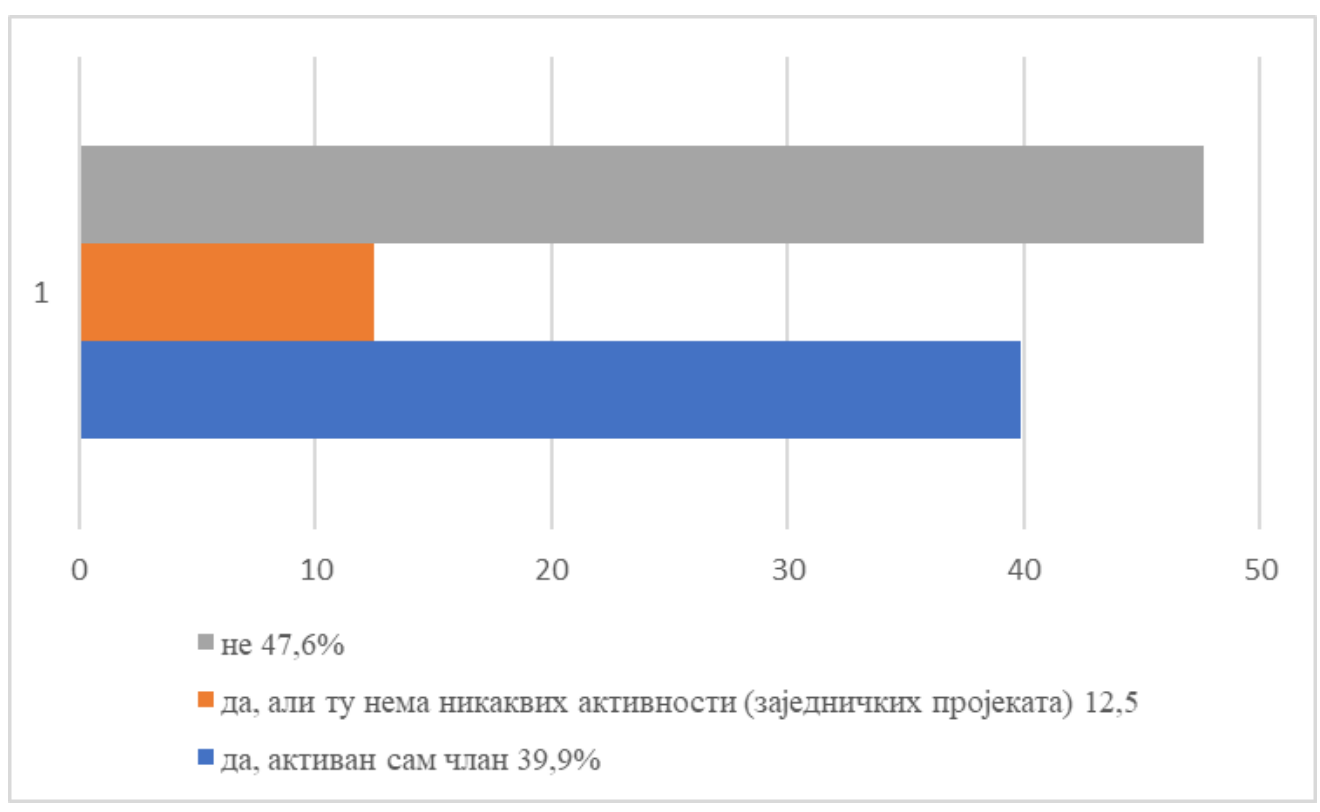

Извор: истраживање „Карактеристике и ставови висококвалификоване дијаспоре и повратника"

Строго се држећи приказаних резултата, можемо рећи да скоро половина испитаника није изградила чврсте везе са стручњацима из своје области, те им у том погледу одлазак у иностранство и није претерано користио. Међутим, не само да остављамо могућност, већ верујемо у постојање врло чврстих веза са стручњацима и колегама са факултета различитих националности који нису добили формалну потврду. Стога, остављамо могућност да је овај ресурс још богатији од овде приказаног. Више забрињава горе приказана транснационална сарадња, у смислу реализације пројеката, која је забележена код нешто више од трећине испитаника. Сличан резултат формалне умрежености, са још мањим уделом испитаника који су остварили транснационалну сарадњу, бележе одговори на питање о чланству у дијаспорским заједницама (графикон 2). 
Графикон 2. Чланство испитаника у дијаспорским заједницама

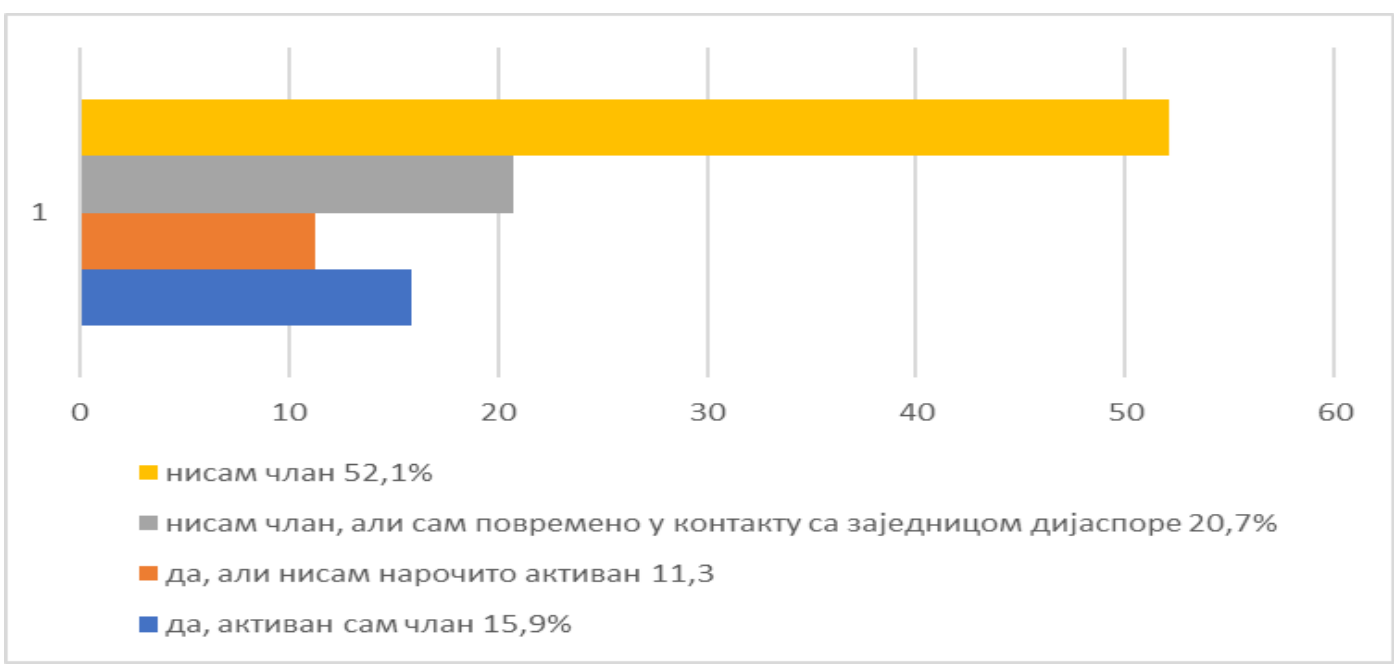

Извор: „Карактеристике и ставови висококвалификоване дијаспоре и повратника“

Приказани резултати показују да више од половине испитаника није члан дијаспорских организација, али претпостављамо да и овде као и у претходном случају, ова умреженост бива реализована независно од формализације контаката. Развој интернета, фејсбук и вајбер групе данас постају место и форма окупљања чланова са заједничким групним идентитетом пре него регистроване организације. Даље, лични контакти који остају незабележени остају најефектнији начин грађења односа и размене ресурса. Видећемо у наредном делу да је неформална комуникација испитаника врло ефикасна и да у том смислу испитаници негују „јаке“ везе са својим сународницима са којима не живе у истој држави 6.

\footnotetext{
6 Реч је о такозваном везујућем социјалном капиталу који је усмерен ка унутра и тежи да ојача ексклузивне идентитет и хомогене групе. Примери повезујућег капитала се односе на породицу, родбину, класу као и етничке братске заједнице, групе женских читалаца повезане на црквеној основи и тсл. (Патнам, 2008: 26). Ова врста социјалног капитала је добра за појачавање специфичног реципроцитета и мобилисање солидарности. Он помаже да се људи држе заједно на основу своје сличности. Везујући социјални капитал је окарактерисан јаким везама и затвореним личним односима. Ова врста социјалног капитала је нека врста „суперлепка“ за заједницу којој у основи стоји јако поверење.
} 
Занимљиво је, међутим, размотрити и ресурсе дијаспоре из њиховог угла, односно шта је по њима највредније што су стекли одласком у иностранство. Одговори испитаника су приказани на следећем графикону.

Графикон 3. Стечене вредности у иностранству према сопственој процени

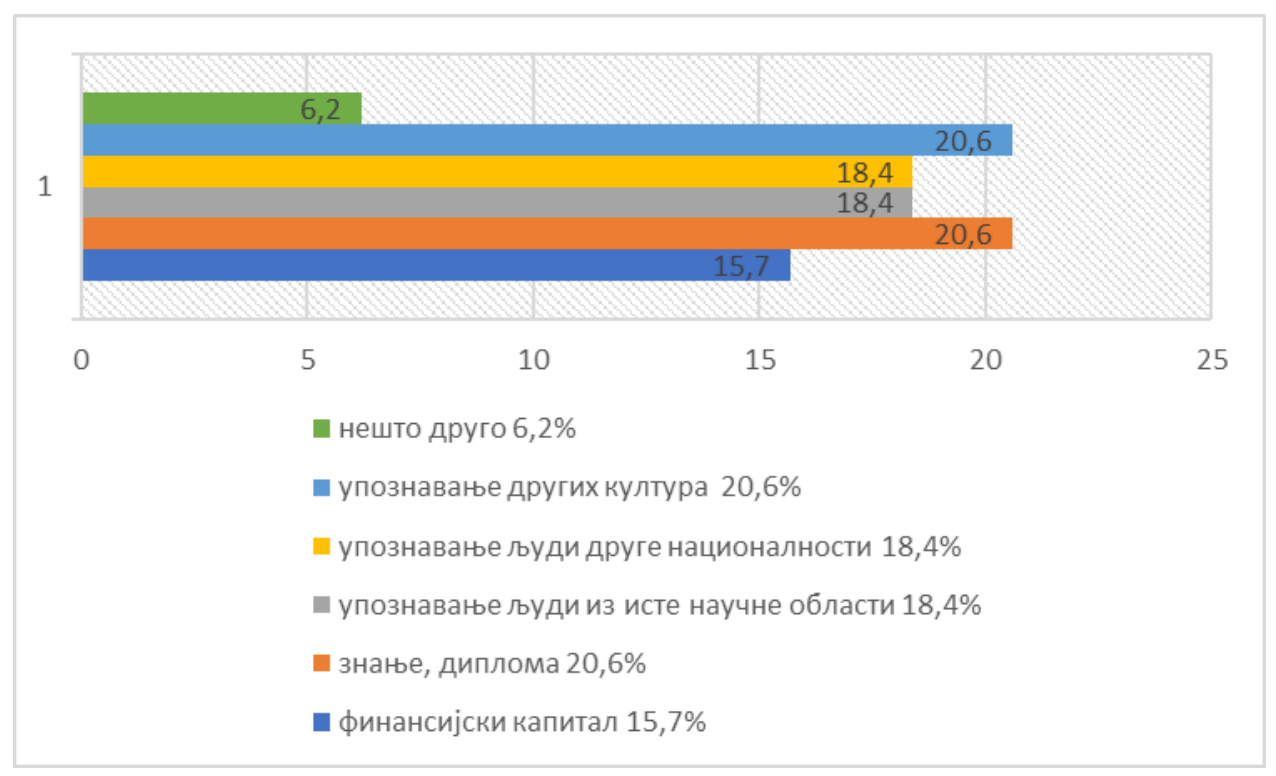

Извор: „Карактеристике и ставови висококвалификоване дијаспоре и повратника“

На основу података изнетих на графикону 3, примећујемо да су испитаници поред очекиваног финансијског, социјалног и хуманог капитала, у великом броју, њих 20,6\%, навели упознавање других култура као посебан бенефит боравка у иностранству. Овај податак не чуди с обзиром на то да многи одлазак у иностранство посматрају и као једини начин да путују и живе ван земље у којој су рођени и то сматрају за велику предност у односу на колеге који се нису одлучили на усавршавање у иностранству, што потврђује и ово истраживање. С друге стране, треба напоменути да је познавање култура од веома великог значаја за потенцијалну билатералну сарадњу матице и земаља у којима су испитаници боравили и као такав овај ресурс не треба да буде занемарен.

\section{Транснационална умреженост са Србијом}

Уз свест о обиму српске научне дијаспоре, али и о савременом обликовању миграционих процеса који карактеришу циркуларност и 
мобилност, који не подразумевају само одлазак у иностранство уз потенцијални коначни повратак након „обављеног посла“, идеја пројекта је била да се пре свега размотре услови за „виртуелни“ повратак ове популације. То би подразумевало усмеравање ресурса стручњака из дијаспоре у развојне пројекте независно од њиховог места боравка. То даље значи одржавање веза и стварање повољне климе за сарадњу са научном заједицом, стручњацима и другим важним актерима (из привреде, политике...) са циљем реализације пројеката који би били усмерени на потенцијални развој у разним областима. Стога, прво смо преко питања о учесталости њихових долазака у Србију и учесталости и врсти контаката са грађанима који живе у Србији испитали у којој мери су контакти и везе одржане независно од моделирања политичке и економске климе. На графикону 4. видимо да је врло мали удео оних чији је одлазак био само у једном правцу, односно да не подразумева долазак у земљу порекла - свега $0,9 \%$.

Графикон 4. Учесталост доласка у Србију

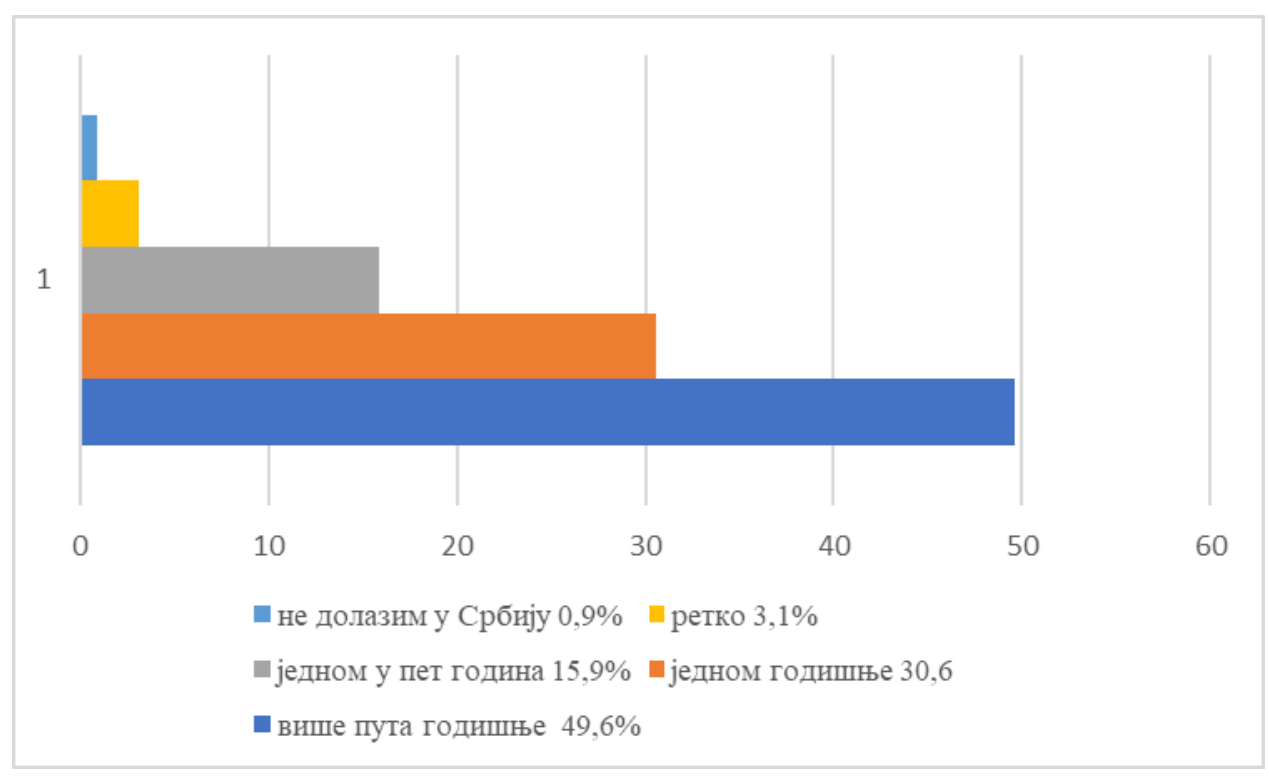

Извор: „Карактеристике и ставови висококвалификоване дијаспоре и повратника“

Примећујемо да приближно 80\% испитаника долази макар једном у земљу, што појачава могућност њиховог укључивања у друштвени развој. Томе треба и додати да је 82,2\% испитаника навело да свакодневно и по 
више пута комуницира са неким из Србије, што, поред потврде опстанка јаких веза, појачава могућности за потенцијално партнерство. Међутим, евентуални проблем може да представља што је веома мали број њих навео да комуницира са пословним партнерима $(3,7 \%)$ или колегама из исте научне области $(12,8 \%)$. Код већине испитаника се комуникација одвија са породицом (46,7\%) или пријатељима - њих 36,3\%. Уз то, свега 20\% испитаника је навело да су учествовали у релизацији неког пројекта са Србијом, што је заиста мали удео с обзиром на наведене развијене везе са земљом. Томе треба додати и податак да 17,2\% анкетираних исказује потпуну спремност да учествује у реализацији пројеката у земљи. Ако томе прикључимо и удео од 56,2\% испитаника који би учествовали зависно од пројекта, увиђамо да је потенцијал који високообразована дијаспоре има, у Србији у великој мери неискоришћен. Посматрано из теоријске перспективе, односно Патнамовог схватања социјалног капитала који тврди истина слабо ефектне, али веома развијене тзв. „слабе“ мреже, можемо рећи да су, бар када је у питању социјални капитал српске научне дијаспоре усмерен на матицу, чврсте рођачке и пријатељске везе ипак примарно очуване, за разлику од ових ширих. Транснационална сарадња у областима интересовања је врло мало развијена.

\section{Стварање климе за потенцијално улагање у развојне пројекте у Србији}

На почетку да наведемо да већина испитаника, њих 57,7\% који су учествовали у реализацији пројеката са партнерима из Србије, том приликом нису имали никаквих проблема. Остатак на првом месту наводи проблеме са компликованом администрацијом, њих 18,3\%, затим непостојање адекватних услова за сарадњу (12,7\%) и на крају 11,3\% испитаника сматра да институцијама у Србији недостаје професионализам и одговорност у пословању. Генерално гледано, независно од тога да ли је сарадња остварена или се код испитаника показује спремност на сарадњу, примећује се да дијаспора препознаје извесне проблеме у овдашњем друштвеном систему, у јавним политикама и њиховој примени, при чему се, што се види из графикона 5., издваја однос државе према њима. Сматрамо да је управо недовољна отвореност и промоција сарадње и равноправног партнерства препрека за реализацију потенцијала које показује ова популација, али и слабо одржавање контаката са стручњацима у земљи. 
Графикон 5. Замерке доносиоцима одлука

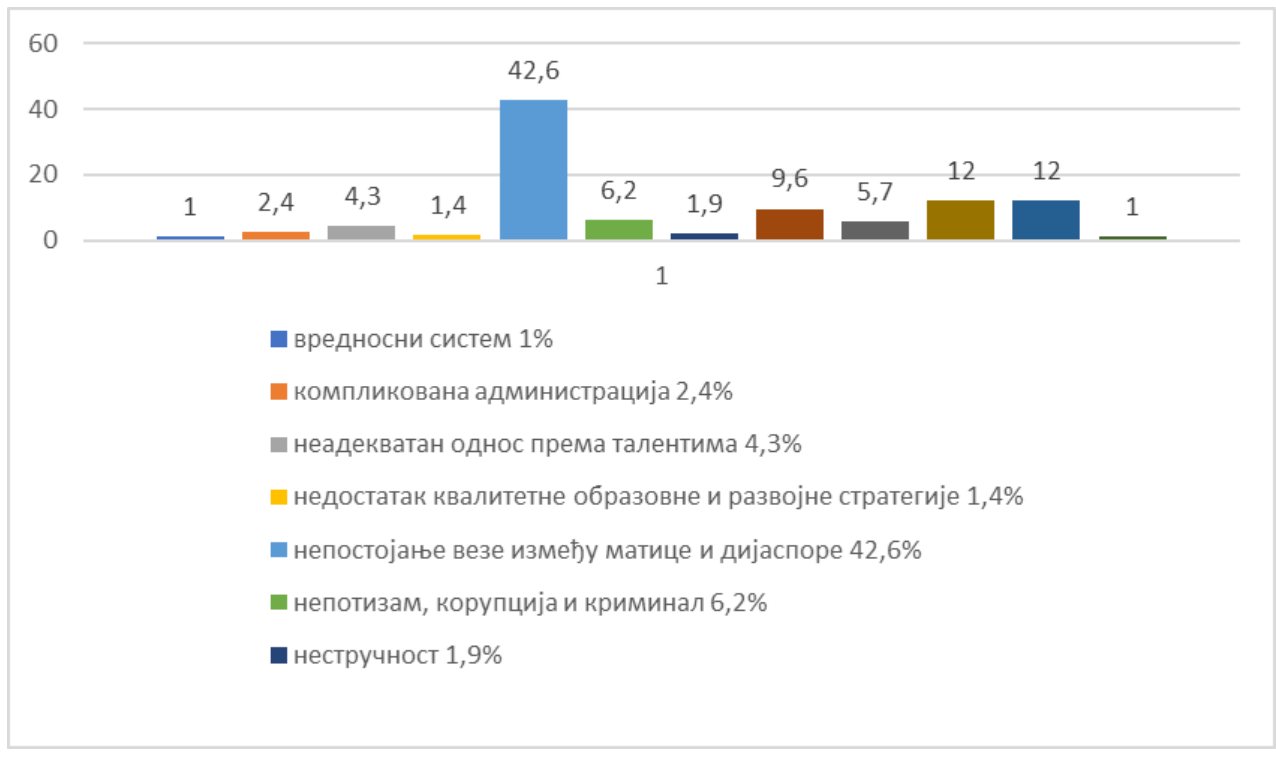

Извор: „Карактеристике и ставови висококвалификоване дијаспоре и повратника“

Имајући ово у виду, јасно је да друштвени систем мора бити значајно измењен како би се у што већем броју дијаспора мотивисала на сарадњу. Смернице преобликовања тренутног стања у Србији, испитивали смо преко питања о мотивима на реализацију сарадње, који су приказани на графикону 6.

Судећи према одговорима на претходно питање, где је велики удео испитаника који препознају недостатак везе матице и дијаспоре, очекивано је било да ће се приликом одабира мотива за сарадњу највећи број анкетираних одлучити за неопходност успостављања поверења у матицу које је неопходно за партнерство. У супротном, нестабилан терен остаје демотивишући за било какво улагање. С тим у вези стоји и проблем непотизма и корупције, који је био заступљен у 17,6\% одговора испитаника. Страначко запошљавање и велики значај родбинских и пријатељских веза остају демотивишући фактор за покушаје било какве сарадње. Дијаспора, видимо, не преферира економско благостање како би уложила знање и идеје, већ рачуна на меритократију која подразумева вредновање знања и способности што је први корак за враћање поверења и потенцијално удруживање са циљем развоја земље на свим нивоима. Пре свега, дијаспора истиче да им је важно да буду препознати као потенцијални партнери што 
се прво чини отвореношћу, административним олакшицама и јавним позивима за сарадњу у земљи.

Графикон 6. Мотиви за сарадњу са Србијом

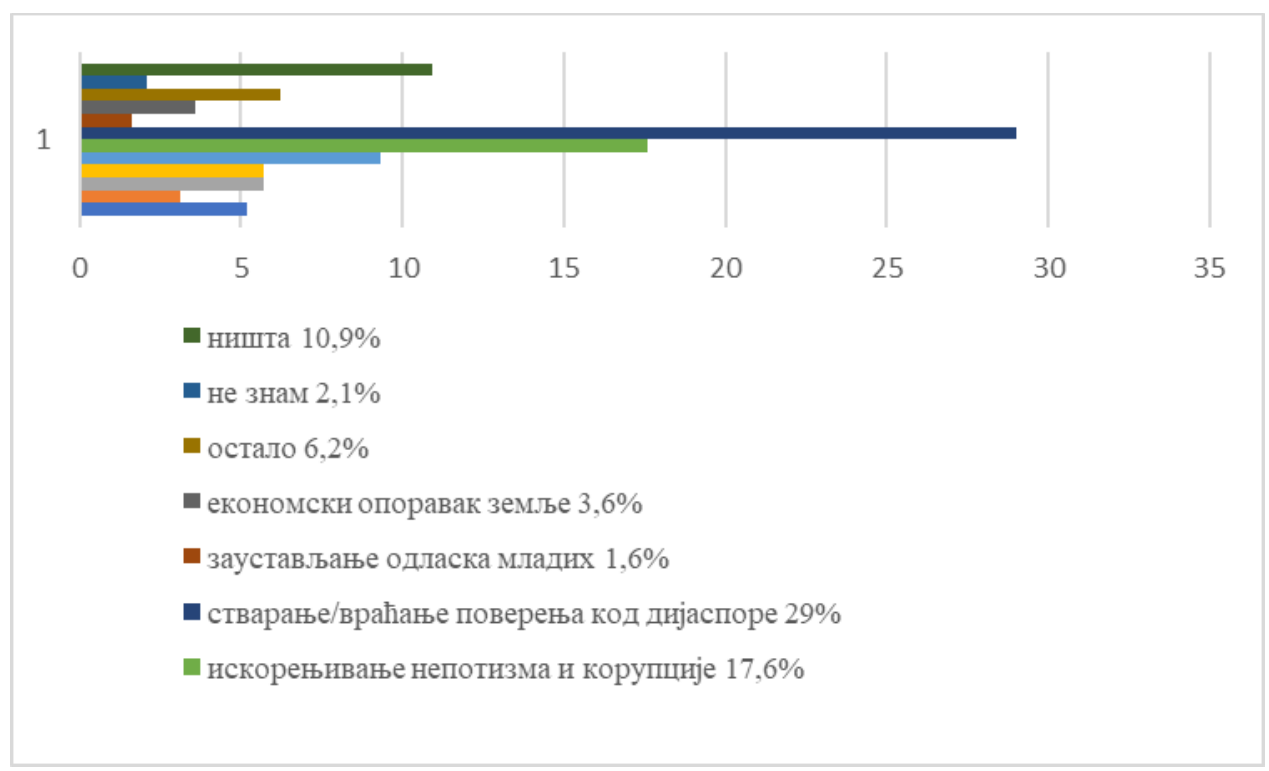

Извор: „Карактеристике и ставови висококвалификоване дијаспоре и повратника“

\section{Закључак}

Промена савременог света коју карактеришу готово треутна комуникација, брзи и релативно приступачан транспорт робе и људи, као и пословање фирми у различитим земљама уз непрекидну размену идеја, условила је и измену значења концепата миграција и дијаспоре, што је даље утицало и на преобликовање државних јавних политика усмерених на миграциону популацију. Миграције данас, дакле, не подразумевају „карту у једном смеру“, веома мали број миграната одлази у једну државу без намере да се, ако се укаже боља прилика, пресели у неку другу, или, ако процени да је на добитку, врати у своју земљу порекла. Мобилност, коју карактерише честа промена места јесте суштина миграционих процеса савременог доба. Даље, дијаспора у великој мери одступа од првобитне дефиниције која подразумева расејање становништва једне земље по целом свету и користи предности информационих технологија које олакшавају комуникацију и учвршћују везе међу свим члановима који не живе у земљи порекла а 
сматрају је за матицу. Ова усмереност чланова дијаспоре једних на друге и препознавање матице као центра интреса, отворили су могућности за креирање политика за управљање миграцијама које за циљ имају добробит свих учесника у миграционом процесу, тзв. „win-win“ опција. Истраживање које смо у раду представили је и креирано на темељу овог уверења.

Анализа представљених резултата нам је показала да имамо дијаспору која поред финансијског капитала (који несумњиво има велики удео у нашем БДП-у) поседује вема богат хумани капитал, као и социјалне ресурсе који нису толико уграђени у формалне структуре у смислу чланства у организацијама, колико се показују у неформалној комуникацији са стручњацима из области којој припадају и појединцима које су упознали током студија. Такође, показало се да научна дијаспора гради веома јаке транснационалне мреже односа са становништвом у Србији, али првенствено са појединцима који су им блиски у приватном животу, а нешто ређе са колегама и пословним партнерима. Но, упркос томе, резултати указују на веома изражену вољу испитаника да учествују у развојним пројектима у Србији. Међутим, док год се не покаже јасан интерес за партнерством са дијаспором, ресурси којима располажу неће бити усмерени у земљу.

Важно је нагласити да и после толико година трансформације друштвеног поретка у Србији, правни, политички, економски и вредносни систем који је овде актуелан треба реструктуирати и уредити тако да буде предвидив и на тај начин створи повољну и сигурну друштвено економску климу за улагања. Судећи према одговорима испитаника, треба започети од искорењивања непотизма и корупције на свим нивоима и увођења меритократије, што је и једини начин за даљу исправну реформу система. Како би се укључили у пројекте у земљи, важно је уредити администрацију, променити однос према талентима, издвојити више за науку и развој, што би све заједно, с једне стране, умањило велики одлив младог образованог становништва, a, са друге, отворило врата за реални или виртуелни повратак стручњака који су земљу напустили. 


\section{Литература}

Bradatan C., R. Melton and A. Popan (2010). Transnationality as a fluid social identity, Social Identities, Vol. 16, No. 2, pp. 169-178.

Vertovec, S. (2001). Transnational Social Formations: Towards Conceptual Cross-Fertilization, Paper presented at the workshop on Transnational Migration: Comparative Perspectives, Princeton University, https://www.researchgate.net/publication/240638360_Transnational_social_fo rmations_Towards_conceptual_cross-fertilization_WPTC-01-16 , приступљено 20.7.2021.

Vertovec, S. (2002). Transnational Networks and Skilled Labour Migrations, Paper presented at the conference of Ladenburger Diskurs 'Migration', Ladenburg: Gottlieb Daimley und Karl Benz-Stiftung, http://www.transcomm.ox.ac.uk/working\%20papers/WPTC0202\%20Vertovec. pdf , приступљено 22.7.2021.

Glick S. (2003). The Centrality of Ethnography in the Study of Transnational Migration: Seeing the Wetland Instead of the Swamp. In Glick Schiller \& N. Foner (eds.) American Arrivals: Anthropology Engages the New Immigration. Manchester: School of American Research.

Гречић, В. (2010). Српска научна дијаспора, Београд: Институт за међународну политику и привреду.

Ђукић Дејановић и група аутора (2018). Карактеристике и ставови висококвалификоване дијаспоре и повратника, Београд: Центар за живот да нас буде више и АТЦ.

Лазић, М. (2014). Увод, у Лазић М. ур, Економска елита у Србији у периоду консолидације капиталистичког поретка, Београд: ИСИ ФФ и Чигоја Штампа, str. 9 - 36.

Ma Mung, E. (2004). Dispersal as a Resource, Diaspora: A Journal of Transnational Studies, Vol. 13, No. 2/3.

Morokvašić M. (2011). Transnational mobility og the Highly Skilled. Chalenges for Serbia and Western Balkans, in Polovina N. and T. Pavlov eds, Mobility and Emigration of Professional and Social Gains and Losses, Beograd: Group 484, Centre for Migration and Intercultural Studies and Institute for Educational Research. 
Патнам, Р. Д. (2008). Куглати сам. Слом и обнова америчке заједнице, Нови Сад: Medditeran Publishing.

Portes, A, C. Escobar, Radford A. W. (2007). Immigrant Transnational Organizations and Development: A Comparative Study, in International Migration Review, Vol. 41, No1, 242 - 281.

Pries, L. (2005). Configurations of geographic and societal spaces: a sociological proposal between 'methodological nationalism' and the 'spaces of flows', Global Networks, Vol. 5, No. 2, pp. 167 - 190.

Sheffer, G. (1986). A New Field of Study: Modern Diasporas in International Politics, in Sheffer, G. (ed.) Modern Diasporas in International Politics, London and Sydney: Croom Helm.

Станковић, В. (2014). Србија у прощесу спољних миграција, Попис становништва, домаћинстава и станова 2011. у Републици Србији, Београд: Републички завод за статистику.

Filipović, J. (2012). Management of a Diaspora Virtual University as a Complex Organization, Serbian Diaspora Virtual University: An Emerging Leadership of a Nation, Lambert Academic Publishing, Saarbrücken.

Faist, T. (2000). Transnationalization in International Migration: Implications for the Study of Citizenship and Culture, Ethnic and Racial Studies, Vol. 23., No. 2., pp. $189-222$.

Coleman J. S. (1988). Social Capital in the Creation of Human Capital, The American Journal of Sociology, Vol. 94., pp. 95-120.

The World Bank (2021). Migration and Remittance Data, доступно на https://www.worldbank.org/en/topic/migrationremittancesdiasporaissues/bri ef/migration-remittances-data , приступљено 17.9.2021. 


\title{
Milica Vesković Andjelković
}

\section{Transnational Networking of High Qualificated Diaspora and Developing of Serbia}

\begin{abstract}
Summary
Mutual networking of person who live in different parts of the world, but outside the home country, which consist of emotional, spiritual and hylic connection with Motherland (that could be only virtual) is at the core of diaspora concept. Both of those concepts (transnationalism and diaspora) are results of contemporary societal phenomena and confuse them could be normal. At this point, we should come apart these concepts. Even though the concept of transnationalism was made for denoting networking of migrants with same origin but live in different countries, it is a wider concept which involves every computation that takes place independent of national state borders. On the other hand, the concept of diaspora, despite of being narrower than the concept of transnationalism, it is in strong relationship with that concept - if there weren't immigrants networking, we couldn't speak about diaspora but dispersion. Furthermore, migration would be loss for the home country, if there weren't transnational networking. Interrelating of immigrants, their readiness to cooperate with each other and with people in the Motherland, their readiness to invest of their human, social and economic capital are the main resource for developing of every society subsystem in the Motherland. The main of this article is analysis if Serbian diaspora who have high qualifications and therefore could be an important resource for development. For analyses, we'll use data which are collected in research which was done by NGO "Center for life" in cooperation with the Minister without portfolio responsible for demography and population policy and Statistical Office of the Republic of Serbia. We'll present educational and economic structure of respondents, their readiness to invest their capital in the Motherland and their recommendation to responsible actors in Serbia.
\end{abstract}

Key words: transnationalism, diaspora, networks, social capital, public policy 